\title{
Disruptive Technology as Antecedent to CEO Pay-Performance Sensitivity
}

\author{
Rebecca Abraham, Judith Harris, Joel Auerbach \\ Huizenga School of Business, Nova Southeastern University, Fort Lauderdale, USA \\ Email: Abraham@nova.edu, harrisj@nova.edu
}

Received 25 January 2015; accepted 9 March 2015; published 11 March 2015

Copyright (C) 2015 by authors and Scientific Research Publishing Inc.

This work is licensed under the Creative Commons Attribution International License (CC BY). http://creativecommons.org/licenses/by/4.0/

(c) (i) Open Access

\section{Abstract}

This study examines the influence of disruptive technology on firm performance, which in turn explains CEO compensation. Innovation consists of a series of S-curves which progress from introduction to growth, maturity and decline until they are replaced by new technology which has its own $S$ curve. Each $S$ curve involves the introduction of products that are cheaper, simpler, smaller and more convenient than established technology by catering to specific market needs currently unserved by existing technology. Disruptive technology is a special case of innovation characterized by its ability to displace a mainstream competitor, while innovation displaces existing technology. This study follows on earlier empirical research that observed that a sample of technology-intensive US firms listed on the NASDAQ from 1993-2012 rewarded CEOs for engaging in disruptive technology by increasing their compensation in the form of stock option grants, suggesting that the effective implementation of disruptive technology results in superior firm performance which is rewarded with incentive pay such as stock option grants. We provide empirical support for the thesis that the implementation of disruptive technology increases net income and subsequently increases incentive pay. Such positive effects of disruptive technology on net income are strengthened for CEOs of higher age, longer tenure, more education and if the CEO is a founder or a celebrity and for larger firms. We draw on the literature on the influence of demographic characteristics on the implantation of innovation to explain the positive interaction of disruptive technology with demographic characteristics which in turn, improve corporate financial performance and consequently increase CEO incentive compensation.

\section{Keywords}

CEO Pay-Performance Sensitivity, Disruptive Technology, Age, Tenure, Education, Founder

\section{Introduction}

The Schumpeterian Theory of Innovation views innovation as the rejuvenation of the natural progression of the 
product life cycle (Schumpeter [1]). Products move through a product life cycle with high initial sales as the product gains market acceptance, flat sales as the product matures, and decline in sales and costs leading ultimately to obsolescence. In this respect, innovation is the production of a succession of new products at higher levels of technological advancement. In the microcomputer industry, personal computers became cheaper and light weight. The linear model consisted of the successive changes to the personal computer in a sequence from $\mathrm{R} \& \mathrm{D}$ to production engineering to marketing. Dot-matrix printers gave way to inkjet printers to laser printers, each higher level of technology offering greater efficiency. No industries were threatened with these changes as each product obsolesced at the end of its S curve to be replaced by another S curve. This is a technological strategy.

Disruptive technology displaces the market leader in a competitive strategy. For example, the leader in the film rental industry offered films on DVD in store for overnight rental. With the advent of the Internet, a startup commenced offering films at a flat subscription rate with instantaneous access through the Internet, and an extensive array of titles with which the in-store rental service could not compete. Initially, subscriptions could only be sold to the fringe market that had Internet access. Eventually, as Internet access became widespread, the subscription service entered the mainstream market displacing the incumbent firm. Johnson et al. [2], who coined the term disruptive technology, described this process as 1) initial underperformance by the disruptive technology, 2) location of the disruptive technology in the fringe market, 3) Steady improvement in performance of the disruptive technology until it meets the standards demanded by the mainstream market, and finally, 4) displacement of the dominant firm by the firm that owns the disruptive technology. While it may be argued that the first three phases are present with all innovations, the final phase of displacement of the dominant firm (and not merely, displacement of the dominant technology) is unique to disruptive technology. Historically, the displacement of sailing ships by steamships, horses and wagons by the automobile, railroads by airlines for passenger travel and by trucks for freight were cases of disruptive technology. Contemporaneously, online retail stores are displacing brick and mortar retailers, laptops displaced desktops, and smart phones displaced the original cell phones.

In an assessment of CEO Pay-Performance sensitivity, Abraham et al. [3] found that for a sample of hightechnology firms listed on the NASDAQ, disruptive technology was the predictor of CEO incentive pay such as stock option grants. In other words, the ability to incorporate disruptive technology in new products was viewed as such a valuable attribute for CEOs that firms paid additional sums in terms of the right to purchase shares of stock at preferred rates to those CEOs in whom this skill was vested. It is significant that CEOs are rewarded with higher incentive pay rather than base pay. In technology-intensive firms innovation that produces a stream of new products is a normal expectation. The aforementioned Abraham et al. [3] study observed that research and development to create innovations enhanced firm revenue which in turn, had no significant influence on CEO incentive pay. Firms expected CEOs to engage actively in new product production which increased sales; however, since these innovations did not contribute significantly to profit, CEOs were not rewarded with additional compensation beyond their base salaries. Only firms in which innovations displaced leading competitors, i.e. disruptive technology were CEOs compensated with incentive pay. Was disruptive technology responsible for considerable increases in profit so that firms that engaged in it compensated CEOs accordingly? In a crosscultural comparison of innovation in technology-intensive firms, Tell is [4] observed that firms with visionary leadership encouraged the development of an internal culture that promoted disruptive technology. There are demographic characteristics such as CEO age, tenure, education, founder-status and celebrity-status that may lead to the effective management of disruptive technology so that such technology increases firm profit to the extent that CEOs are rewarded for it. Given that firm size has been found in successive studies to significantly predict CEO compensation in up to $30 \%$ of public and privately-held firms (Kostiuk [5]; Murphy [6]; Rosen [7]) does the ability of disruptive innovation to explain financial performance and CEO incentive pay increase with firm size?

How should financial performance be measured? Abraham et al. [3] compared measures of financial performance, finding that of stock returns, net income, net operating income and revenue, only net income significantly explained CEO incentive pay. It appears that, for technology-intensive firms profitability determines CEOintensive pay. Profitability is the ultimate income statement measure obtained after all expenses have been deducted. Could firms that engage in disruptive technology reward CEOs based on their ability to generate final profits rather than intermediate quantities such as net operating income and revenue or market-based transient measures such as stock returns? It is to the questions that this study is directed. 


\section{Hypotheses Development}

\subsection{Disruptive Technology}

Stewardship theory views management as a cooperative effort between stakeholders including employees, managers and customers. All parties are in agreement that aligning personal goals with organizational goals promotes utility over individual, self-serving behavior (Davis, Schoorman, \& Donaldson, [8]; Donaldson \& Davis, [9]). The effective management of disruptive technology assumes such cooperation in that there is first the need for employees to believe in management's desire to meet customer needs in a novel fashion hitherto unserved by incumbents. Employees must unite behind management as it pursues new, possibly personally destabilizing paths to earn future revenue. For example, when Gerstner at IBM took the decision to subordinate hardware production in favor of large-scale data processing services, employees who had been engaged in hardware production readily accepted the need to make the change for mutual future benefit. Customers such as large multinationals with operations in multiple countries demonstrated faith in IBM's ability to provide customized data processing solutions. Disruptive technology assumes willingness to accept risk. The necessity of cannibalizing existing assets to invest in technology that is initially less effective in meeting mainstream market needs requires a propensity for risk-taking that envisions the link between the current product meeting specialized market needs and an enhanced product meeting mainstream needs in the future. Stewardship upholds such risk-taking in that CEOs who sacrifice current profits to take a leap of faith with new products are motivated by the genuine belief that such action furthers the long-term interests of the firm (Chandy and Tell is, [10]). Employees who view themselves as stewards actively engage in the disruptive technology-induced need for continuous product improvement to make new products cheaper, faster and more capable of meeting mainstream market needs until the new product replaces the mainstream product entirely. Such employees do not question the additional effort required as they perceive personal utility in it.

Stewardship theory underscores the psychological underpinnings of the effective management of disruptive technology. Intrinsic motivation characterized by self-efficacy and self-determination of employee goals drives stewards who create novel procedures for task completion to implement disruptive technology. Stewards identify with their organizations. Davis, Schoorman and Donaldson [8] set forth that individuals who identify with their organizations display cooperation, altruism and citizenship (O’Reilly and Chatman, [11]). They are motivated to assist the organization to succeed and are motivated to perform their jobs as this furthers organizational success. Such identification and motivation binds employees to the organization. This value commitment, or belief and acceptance of the goals of the organization is essential for accepting the need for the arduous process of continuous product improvement till the fringe product is accepted widely or for the successful implementation of disruptive technology.

Hypothesis 1: The management of disruptive technology increases net income, which increases CEO incentive pay.

\subsection{Disruptive Technology and Firm Size as Predictors of Net Income Which Predicts CEO Pay}

In the context of firm size, Schumpeter [1] maintained that large firms innovate more intensively than small firms. Galbraith [12] and Ali [13] supported this position postulating that economies of scale in research and development, the ability to spread risk and greater access to financial resources permit large firms to be more innovative than their smaller counterparts. We may extend these advantages to the effective management of disruptive technology. Further, the Tosi et al.'s [14] managerial power hypothesis may prevail with larger firms providing increasing compensation over smaller firms. Both Anderson et al. [15] and Shim et al. [16] found that firm size explained CEO performance in high-technology firms during the 1996-2003 time period. Anderson et $a l$. [15] reason that larger firms hire better managers and in order to stay competitive pay higher wages. Shim et al. [16] found highly significant relationships between firm size and three separate measures of compensation for both high and low technology firms, suggesting that the influence of firm size on compensation is independent of industry effects. In other non industry-specific studies, firm size has been found to be the most powerful determinant of CEO compensation explaining up to $30 \%$ of the variation in CEO pay in both publicly-held and privately-owned firms. Tosi et al. [14] provide the rationale for the importance of firm size setting forth that increasing size reduces risk and provides an alternate performance criterion to financial performance. Brook man and Thistle [17] regressed CEO compensation on lagged stock returns, return on assets, the log of assets and le- 
verage. Significant coefficients of 0.29 - 0.40 were observed on the log of assets. In an examination of CEO compensation for firms with declining performance, Lin and Kuo [18] observed that firm size (measured as the log of assets) was the only variable that explained both total CEO compensation and CEO cash compensation at the $1 \%$ level. Cole and Mehran [19] used sales rather than assets as their measure of firm size. Pay-size elasticities for public firms were robust to the Brook man and Thistle [17] result while significance was higher for privately-held firms. These results were robust across nine industry groups.

As stated, net income is an income statement measure of firm performance, which is 1) comprehensive in its measure of profit after all expenses have been deducted including cost of production, marketing expenses, administrative expenses, interest expense and taxes, 2) and is an internal financial performance-based measure unlike stock returns which are based on more transient market sentiment. Anderson et al. [15] and Balk in et al. [19] observed the significant influence of return on assets (which includes net income) on CEO pay in technology firms, a general sample consisting of all firms in the Execu Comp database from 1993-2008. Therefore, it is conceivable that CEOs who embrace disruptive technology in their role as stewards of the firm strive to increase net income for which they are rewarded materially.

Hypothesis 2: The interaction of disruptive technology and firm size significantly predicts net income which explains CEO incentive pay.

\subsection{Disruptive Technology and Age $\rightarrow$ Net Income $\rightarrow$ CEO Incentive Pay}

Holmstrom [20] theorized that the talents of older managers are fully known and decisions made by such managers are not talent tests that determine their current or future wages. They may be more willing to assume risk such as in the adoption of disruptive technology as they do not see it as threatening their wages or record of accomplishment with the firm. Scharfstein and Stein [21] supported this market learning model stating that older CEOs are less concerned about labor market scrutiny in the event of taking excessive risk that may jeopardize future career opportunities. To sustain disruptive innovation, CEOs need to continue to make risky decisions and should be compensated for assuming such risk (Finkelstein and Hambrick [22]). It follows that as older CEOs make necessary investments, they may be compensated with performance-sensitive compensation. There is some empirical support for this conjecture with Smith and Watts [23], Gaver and Gaver [24] and Baber, Janakiraman and King [25] finding that firms with more investment opportunities provide more incentive pay and Guay [26] observing that such pay is more sensitive to equity risk. Intuitively, age increases maturity so that mature CEOs may be more skilled at knowing when to divert resources from established projects to disruptive technology, the optimal time to move from the fringe market to the mainstream market and the preferred method of allocation of physical and human resources for continuous product improvement.

Hypothesis 3: The interaction of disruptive technology and age significantly predicts net income which explains CEO incentive pay.

\subsection{Disruptive Technology and Tenure $\rightarrow$ Net Income $\rightarrow$ CEO Incentive Pay}

Tenured CEOs who have retained employment at a technology-intensive firm may be more likely to engage in disruptive technology. Such CEOs evolve through a trial-and-error phase in which they experiment with different types of innovations, possibly pursue less profitable projects, reallocate resources to more promising technologies, and hire and terminate scientists and engineers. In other words, there is a learning process of experimentation and self-development. We posit that CEOs who have undertaken this type of learning with non-disruptive innovations will be more adept at making the decisions for implementation of disruptive technology. In an evaluation of the performance of production heads in the film industry, Miller and Shamsie [27] observed that studio performance rose before a tenure of 14 - 16 years was attained thereby reflecting the benefits of learning and experience. Vintilla and Ghergina [28] used a random sample of 155 companies to measure the relationship between CEO tenure and firm performance. They found that CEO tenure significantly increased both return on assets and earnings per share. This finding supports our contention that the experienced management of disruptive technology is not an emotional measure of performance as volatile stock returns predicated on economic fluctuations and political developments can be. ROA and EPS use net income which is the final measure of profitability. Therefore, disruptive technology may be implemented more effectively by tenured CEOs who are rewarded with stock option grants. 
Hypothesis 4: The interaction of disruptive technology and tenure significantly predicts net income which explains CEO incentive pay.

\subsection{Disruptive Technology and Education $\rightarrow$ Net Income $\rightarrow$ CEO Incentive Pay}

Human capital theory (Becker [29]) postulates that employee characteristics such as educational attainment increase earnings over a lifetime. Positive relationships between education and CEO compensation have been found in non-technology intensive industries (Chung and Pruitt [30]; Main, O’Reilly and Wade [31]), though there is a paucity of research in technology-intensive firms. However, the technical nature of new devices, the need to integrate hardware and software, and produce a stream of more technologically sophisticated phones, laptops and tablets suggests the need for increasing educational attainment. Educational attainment among CEOs of technology-intensive US firms listed on the NASDAQ typically consists of a Bachelor's degree often in Electrical Engineering. The few CEOs who have graduate degrees have Master's degrees or doctoral degrees in Electrical Engineering. We suggest that higher educational attainment in the form of graduate degrees may strengthen the successful adoption of disruptive technology which increases net income and CEO equity-based compensation. Graduate degrees require the writing of a thesis or dissertation. The content of a thesis may be the development of a new product or technology. To the extent that the thesis or dissertation must be defended before a faculty committee, the author must present either technical evidence or a combination of technical or marketing evidence. The product may need to demonstrate its ability to be cheaper, faster and more effective at meeting market needs than mainstream products. This is the essence of disruptive technology. Therefore, CEOs who have been exposed to disruptive technology during the educational process may be in a stronger position to implement it effectively to increase profits and incentive-based compensation. The literature relating educational attainment to disruptive technology is nonexistent; hence, we set forth an intuitive explanation.

Hypothesis 5: The interaction of disruptive technology and educational attainment significantly predicts net income which explains CEO incentive pay.

\subsection{Disruptive Technology and CEO Founder-Status $\rightarrow$ Net Income $\rightarrow$ CEO Incentive Pay}

The founder of a technology-intensive firm is a steward. This individual had a creative notion, built a prototype, raised venture capital and embarked upon the production of a novel product line. The product line may have been a disruptive or non disruptive innovation. Over time, the founder may have to engage in the development or acquisition of disruptive technology to ensure firm survival. For example, the founder of one of the firms in the sample just announced his retirement after a career spanning three decades. His original investment was in a series of non disruptive memory devices. After competition intensified in the memory expansion industry, he acquired a firm which had a monopoly in high-level integrative systems. This firm remained in a niche market and therefore, did not complete the process to be deemed disruptive technology. However, over time, the founder acquired expertise in high-level integrative systems leading to his launching an operating platform for such systems that eventually entered the mainstream market. This was disruptive technology born of experience in different types of innovations along with the understanding of the market's need. At present, this disruptive technology still dominates the mainstream market. In successive studies, Villalonga and Amit [32], Palia et al. [33], Adams et al. [34], Fahlenbrach [35] and Vintella and Ghergina [28] found that the founder-status of the CEO significantly increased return on assets. Consequently, we hypothesize that CEO founder-status increases net income and CEO incentive compensation.

Hypothesis 6: The interaction of disruptive technology and CEO founder-status significantly predicts net income which explains CEO incentive pay.

\subsection{Disruptive Technology and CEO Celebrity-Status $\rightarrow$ Net Income $\rightarrow$ CEO Incentive Pay}

CEOs who have achieved celebrity status are frequently efficient resource allocators. They have the visibility and name recognition to access substantial financial resources. They have sufficient funds to continue investment in the existing technology, while initiating investment in the new, disruptive technology. This investment in the disruptive technology is likely to increase net income and incentive pay.

Hypothesis 7: The interaction of disruptive technology and CEO celebrity-status significantly predicts net income which explains CEO incentive pay. 


\section{Data and Methodology}

All firms listed on the NASDAQ from 1993-2011 were screened for inclusion in the sample. After exclusion of non-US firms and those firms engaged exclusively in the marketing of technology such as advertising and radio and television, the final sample consisted of 431 firms. These firms were classified as producers of computer software, non-computer industrial machinery, semiconductors, electronic data processing services, semiconductors, computer hardware, computer peripherals, electrical products, retail computer software, electronic components and computer communications. Stock prices were extracted from the CRSP (Center for Research in Security Prices) database. COMPUSTAT acted as the source for financial statement data including total assets (measuring size), stockholders' equity and net income. Corporate reports of executive profiles provided demographic information on CEOs including age and tenure (measured in number of years), education ( $1 \mathrm{for}$ an undergraduate degree and 2 for one or more graduate degrees), CEO-founder duality (a dichotomous variable assuming values of 0 for CEOs who were not founders or 1 for CEOs exhibiting CEO-founder duality) and celebrity status from news reports (CEOs whose names appeared in news reports were deemed celebrities scoring 1 while those whose names did not appear in news reports scored 0). Disruptive technology was measured as a dichotomous variable with values of 1 if a subjective assessment determined that a single product line displaced the competition or values of 0 all product lines coexisted with the competition.

The compensation variables of salary, dollar value of stock option grants and total compensation were obtained from DEF 14A of the annual EDGAR filings with the Securities and Exchange Commission. Total compensation was the sum of all sources of compensation including salary, stock awards, stock option grants and unspecified long-term compensation payouts. Descriptive statistics and correlations of relevant variables are contained in Table 1. Correlations were significant at the 0.05 level for age and stock option grants and age and total compensation ( $r=0.10$ and $r=0.19$, respectively), size and stock option grants and size and total compensation with size represented as total assets $(r=0.10$ and $r=0.15$, respectively), net income and stock option grants and net income and total compensation $(r=0.07$ and $r=0.12$, respectively). The significance of these intercorrelations suggested that age, firm size and net income were significant predictors of incentive pay in the form of stock option grants as hypothesized in hypotheses 1 - 3.

Hypotheses 1 - 7 were tested using a vector autoregressive model that assumed that disruptive technology and demographic characteristics remained exogenous, while net income was both exogenous and endogenous and incentive pay was endogenous. The 7 component regressions may be represented as follows:

$$
\begin{aligned}
& \mathrm{OPT}=a+b_{1} \mathrm{NETINC}+e \\
& \mathrm{NETINC}=a+b_{2} \mathrm{DISR}+e \\
& \mathrm{OPT}=a+b_{1} \mathrm{NETINC}+e \\
& \mathrm{NETINC}=a+b_{3} \mathrm{DISR} \times \mathrm{SIZE}+e \\
& \mathrm{OPT}=a+b_{1} \mathrm{NETINC}+e \\
& \mathrm{NETINC}=a+b_{4} \mathrm{DISR} \times \mathrm{AGE}+e \\
& \mathrm{OPT}=a+b_{1} \mathrm{NETINC}+e \\
& \mathrm{NETINC}=a+b_{5} \mathrm{DISR} \times \mathrm{TEN}+e \\
& \mathrm{OPT}=a+b_{1} \mathrm{NETINC}+e \\
& \mathrm{NETINC}=a+b_{6} \mathrm{DISR} \times \mathrm{EDUCATION}+e \\
& \mathrm{OPT}=a+b_{1} \mathrm{NETINC}+e \\
& \mathrm{NETINC}=a+b_{7} \mathrm{DISR} \times \mathrm{FOU}+e \\
& \mathrm{OPT}=a+b_{1} \mathrm{NETINC}+e \\
& \mathrm{NETINC}=a+b_{8} \mathrm{DISR} \times \mathrm{CELE}+e
\end{aligned}
$$

an additional vector auto regression was performed to measure the combined effect of disruptive technology and ability to fund growth on net income and CEO incentive pay. These relationships may be represented as: 
Table 1. Descriptive statistics and correlations.

\begin{tabular}{cccc}
\hline Variable & Mean & Correlation of Incentive Pay & $\begin{array}{c}\text { Correlation of Total } \\
\text { Compensation }\end{array}$ \\
\hline Option Grants & $\$ 7,988,978(\$ 714,688)$ & 1 & 0.58 \\
Total Compensation & $\$ 31,088,873(\$ 1,795,605)$ & 0.58 & 1 \\
Size (Total Assets) & $\$ 1,030,082,860(\$ 6,311)$ & 0.10 & 0.15 \\
Growth (Equity) & $\$ 569,321,000(\$ 2,725.876)$ & 0.00 & 0.02 \\
Net Income & $\$ 75,308,000(\$ 690.88)$ & 0.07 & 0.12 \\
Age & 40.00 years $(23.23$ years) & 0.10 & 0.19 \\
Tenure & 2.5 years $(5.47$ years $)$ & 0.06 & No corr. for categorical \\
variables
\end{tabular}

$$
\begin{aligned}
& \mathrm{OPT}=a+b_{1} \mathrm{NETINC}+e \\
& \mathrm{NETINC}=a+b_{9} \mathrm{DISR} \times \mathrm{GROWTH}+e
\end{aligned}
$$

where

NETINC = Annual net income;

$\mathrm{OPT}=\mathrm{CEO}$ stock option grants;

SIZE = Total assets;

GROWTH = Ability to fund growth measured by stockholders' equity;

AGE = Age of CEO in years;

TEN = Tenure as CEO in years;

EDUCATION = Scored as “ 1 ” for a bachelor's degree and " 2 ” for a graduate degree;

FOU = CEO-FOUNDER duality; " 1 ” for a CEO who is a founder and " 0 " for a CEO who is not a founder;

CELE = " 1 " for a CEO who is a celebrity and " 0 " for a CEO who is not a celebrity;

DISR = “ 1 ” for a firm with disruptive technology and “ 0 ” for a firm with non-disruptive technology.

\section{Results}

As reported in Table 2. Hypotheses 1 - 7 were supported in that disruptive technology exerted a significant influence on net income (coefficient $=21.38, \mathrm{p}<0.001$ ) for hypothesis 1 , the interaction of disruptive technology and size significantly explained net income (coefficient $=10, \mathrm{p}<0.001$ ) for Hypothesis 2 , the interaction of disruptive technology and age (coefficient $=4.44$, p $<0.001$ ) for Hypothesis 3 , the interaction of disruptive technology and tenure which explained net income (coefficient $=8.11$, p $<0.001$ ) for Hypothesis 4 , the interaction of disruptive technology and education which significantly influenced net income (coefficient $=35.01$, p $<0.001$ ) for Hypothesis 5, the interaction of disruptive technology and CEO as founder which significantly predicted net income (coefficient $=20.99, \mathrm{p}<0.001$ ) for Hypothesis 6 and the interaction of disruptive technology and CEO as celebrity which significantly predicted net income (coefficient $=77.96, \mathrm{p}<0.001$ ) for Hypothesis 7 . Alternative nonlinear functional forms such as the quadratic, hyperbolic and logarithm misspecifications yielded no significant result. Net Income significantly predicted two measures of CEO compensation, i.e. incentive pay (coefficient $=77.96, \mathrm{p}<0.001$ ) and total compensation which is composed of both salary and incentive pay (coefficient $=30.90, \mathrm{p}<0.001)$. The additional measure of the CEO’s ability to fund growth was not found to be significant in itself suggesting that the ability to fund growth acts in conjunction with other CEO characteristics to increase net income rather than in itself. 
Table 2. Results of vector auto regressions of net income and CEO incentive pay on disruptive technology and demographic characteristics.

\begin{tabular}{|c|c|}
\hline Path Coefficient & Linear Model \\
\hline \multicolumn{2}{|l|}{ Exogenous criteria } \\
\hline \multicolumn{2}{|l|}{ Hypothesis 1} \\
\hline Disruptive technology predicts net income & $21.38^{* * *}$ \\
\hline Net income predicts incentive pay & $76.32^{* * *}$ \\
\hline \multicolumn{2}{|l|}{ Hypothesis 2} \\
\hline Disruptive technology and firm size predict net income & $10.00^{* * *}$ \\
\hline Net income predicts incentive pay & $76.32^{* * *}$ \\
\hline \multicolumn{2}{|l|}{ Hypothesis 3} \\
\hline Disruptive technology and age predict net income & $4.44^{* * *}$ \\
\hline Net income predicts incentive pay & $76.32^{* * *}$ \\
\hline \multicolumn{2}{|l|}{ Hypothesis 4} \\
\hline Disruptive technology and tenure predict net income & $8.11^{* * *}$ \\
\hline Net income predicts incentive pay & $76.32^{* * *}$ \\
\hline \multicolumn{2}{|l|}{ Hypothesis 5} \\
\hline Disruptive technology and education predict net income & $35.01^{* * *}$ \\
\hline Net income predicts incentive pay & $76.32^{* * *}$ \\
\hline \multicolumn{2}{|l|}{ Hypothesis 6} \\
\hline Disruptive technology and CEO as founder predict net income & $20.99^{* * *}$ \\
\hline Net income predicts incentive pay & $76.32^{* * *}$ \\
\hline \multicolumn{2}{|l|}{ Hypothesis 7} \\
\hline Disruptive technology and CEO as celebrity predict net income & $77.96^{* * *}$ \\
\hline Net income predicts incentive pay & $76.32^{* * *}$ \\
\hline Disruptive technology and CEO ability to fund growth predicts net income & 0.11 \\
\hline Net income predicts total compensation & $30.90^{* * *}$ \\
\hline
\end{tabular}

${ }^{*} \mathrm{p}<0.05, \stackrel{* *}{*}<0.01, \stackrel{* * *}{\mathrm{p}}<0.001$.

\section{Conclusions}

This study empirically supports the adoption of disruptive technology that increases net income which results in CEOs being rewarded with stock option grants in technology-intensive firms. The effective implementation of such disruptive technology is supported by CEOs who are mature, tenured, educated at the graduate level, founders and celebrities in large firms. Such individuals are capable of increasing net income and benefitting from higher incentive pay. The effective management of disruptive technology requires the performance of the functions of 1) resource allocation, i.e. divesting resources from existing technology to the new, disruptive technology, 2) converting intellectual curiosities to profitable products and 3) meeting market needs so effectively that the incumbent firm exits the market. The fulfillment of these functions results in higher incentive pay usually in the form of stock option grants. CEO maturity, tenure and education in a large-firm environment promote effective resource allocation as seasoned managers have more knowledge born from experience. Yet, the status of the CEO primarily as founder and secondarily as celebrity yielded the highest increases in net income and incentive pay. The CEO as founder has the future market orientation to generate products that are continuously improved to match evolving market needs. The underlying psychological factors may be attributed to visionary leadership as Tell is [4] found with CEOs across 13 countries demonstrating the vision to imbue their organizations with cultures that fulfilled the second and third functions listed above. This study maintains that founder-CEOs espouse stewardship theory. In contrast with the self-serving nature of CEOs who embody agency theory, CEOs who are founders are likely to identify with their firms as they originated the firms, and view their own personal interests as being served if the firm's profits are maximized. Future research should test the influence of the interaction of disruptive technology with survey-based measures on net income and CEO incentive pay. Stewardship may act as the impetus for risk-taking. CEOs selected by venture capitalists may use their successful past performance to be selected to oversee the development of a succession of new products, some of 
which are disruptive innovations. The board may have to continue to pay higher compensation to such CEOs to justify its continued support for a CEO whom the board selected. CEOs as celebrities bring visibility and glam or to the firm's products which may be translated into higher sales. Therefore, we may be witnessing a transition underway in technology-intensive firms from a production-orientation with its emphasis on resource allocation to more subjective judgment that provides the CEO with the marketing orientation and insight to provide the product that matches customer needs more effectively than the competition.

This study has the principal managerial implication that CEOs must be trained in stewardship theory. They must adopt the self-concept that their personal interests are served by the continued profitability of the firm.

They must subordinate any desire to promote their own interests at the expense of the firm as set forth by agency theory. In becoming stewards of the firm such CEOs must disseminate their views throughout the organization so that the firm acts in a unified manner to uphold the goal of shareholder wealth maximization. Selection criteria for CEOs who successfully implement disruptive technology include maturity, tenure within the firm, education at the graduate level and celebrity status of the CEO. We assume that founders are self-selected and consequently founder-status may be omitted from selection criteria.

This study contributes to the literature on disruptive technology by being one of the few empirical investigations on this subject. Much of the literature is theoretical or anecdotal (see Johnson et al. for a review [2]). In this regard, other measures of disruptive technology should be developed to supplement this study's use of a dichotomous, binary measure based on the ability of disruptive technology to displace a competitor.

\section{References}

[1] Schumpeter, J.A. (1939) Business Cycles: A Theoretical, Historical, and Statistical Analysis of the Capitalist Process. McGraw-Hill, New York.

[2] Johnson, M., Christensen, C. and Hagermann, K. (2008) Reinventing Your Business Model. Harvard Business Review, 86, 2-11.

[3] Abraham, R., Harris, J. and Auerbach, J. (2014) CEO Pay-Performance Sensitivity: A Multi-Equation Model. Technology and Investment, 5, 125-136. http://dx.doi.org/10.4236/ti.2014.53013

[4] Tellis, G. (2006) Disruptive Technology or Visionary Leadership. Journal of Product Innovation Management, 23, 3438. http://dx.doi.org/10.1111/j.1540-5885.2005.00179.x

[5] Kostiuk, P. (1990) Firm Size and Executive Compensation. Journal of Human Resources, 25, 90-105. http://dx.doi.org/10.2307/145728

[6] Murphy, K.J. (1999) Executive Compensation. In: Ashenfelter, O. and Card, D., Eds., Handbook of Labor Economics, North Holland, Amsterdam, 2485-2563. http://dx.doi.org/10.1016/S1573-4463(99)30024-9

[7] Rosen, S. (1982) Authority, Control and the Distribution of Earnings. Bell Journal of Economics, 13, 311-323. http://dx.doi.org/10.2307/3003456

[8] Davis, J.H., Schoorman, D. and Donaldson, L. (1997) Toward a Stewardship Theory of Management. The Academy of Management Review, 22, 20-47.

[9] Donaldson, L. and Davis, J.H. (1989) CEO Governance and Shareholder Returns: Agency Theory or Stewardship Theory. Paper Presented at the Annual Meeting of the Academy of Management.

[10] Chandy, R.K. and Tellis, G.J. (1998) Organizing for Radical Product Innovation: The Overlooked Role of Willingness to Cannibalize. Journal of Marketing Research, 35, 474-487. http://dx.doi.org/10.2307/3152166

[11] O’Reilly, C. and Chatman, J. (1986) Organizational Commitment and Psychological Attachment: The Effects of Compliance, Identification and Internalization on Prosocial Behavior. Journal of Applied Psychology, 71, 492-499. http://dx.doi.org/10.1037/0021-9010.71.3.492

[12] Galbraith, J.K. (1952) American Capitalism: The Concept of Countervailing Power. Houghton Mifflin, New York.

[13] Ali, A. (1994) Pioneering versus Incremental Innovation: Review and Research Propositions. Journal of Product Innovation Management, 11, 46-61. http://dx.doi.org/10.1016/0737-6782(94)90118-X

[14] Tosi, H., Werner, S., Katz, J. and Gomez-Mejia, L. (2000) How Much Does Performance Matter? A Meta-Analysis of CEO Pay Studies. Journal of Management, 26, 301-339. http://dx.doi.org/10.1177/014920630002600207

[15] Anderson, M.C., Banker, R.D. and Ravindran, S. (2000) Executive Compensation in the Information Technology Industry. Management Science, 46, 530-547. http://dx.doi.org/10.1287/mnsc.46.4.530.12055

[16] Shin, E., Lee, J. and Kajoo, I. (2009) CEO Compensation and US High-Tech and Low-Tech Firms' Corporate Performance. Contemporary Management Research, 5, 93-106. 
[17] Brookman, J.T. and Thistle, P.D. (2013) Managerial Compensation: Luck, Skill or Labor Markets? Journal of Corporate Finance, 21, 252-268.

[18] Lin, D., Kuo, H. and Wang, L.H. (2013) Chief Executive Compensation: An Empirical Study of Fat Cat CEOs. The International Journal of Business and Finance Research, 7, 27-42.

[19] Balkin, D.B., Markman, G.D. and Gomez-Mejia, L.R. (2000) Is CEO Pay in High-Technology Firms Related to Innovation? Academy of Management Journal, 43, 1118-1129. http://dx.doi.org/10.2307/1556340

[20] Holmstrom, B. (1999) Managerial Incentive Problems: A Dynamic Perspective. The Review of Economic Studies, 66, 169-182. http://dx.doi.org/10.1111/1467-937X.00083

[21] Scharfstein, D.S. and Stein, J.C. (1990) Herd Behavior and Investment. The American Economic Review, 80, 465-479.

[22] Finkelstein, S. and Hambrick, D.C. (1996) Top Executives and Their Efforts on Organizations. West Publishing, Minneapolis-St. Paul.

[23] Smith, C.W. and Watts, R.L. (1982) Incentive and Tax Effects of Executive Compensation Plans. Australian Journal of Management, 7, 139-157. http://dx.doi.org/10.1177/031289628200700204

[24] Gaver, J.J. and Gaver, K.M. (1993) Additional Evidence on the Association between the Investment Opportunity Set and Corporate Financing, Dividend, and Compensation Policies. Journal of Accounting and Economics, 16, 125-160. http://dx.doi.org/10.1016/0165-4101(93)90007-3

[25] Baber, W., Janakiraman, S. and King, S. (1996) Investment Opportunities and the Structure of Executive Compensation. Journal of Accounting and Economics, 21, 297-318.

[26] Guay, W.R. (1999) The Sensitivity of CEO Wealth to Equity Risk: An Analysis of the Magnitude and Determinants. Journal of Financial Economics, 53, 43-71. http://dx.doi.org/10.1016/S0304-405X(99)00016-1

[27] Miller, D. and Shamsie, J. (2001) Learning across the Life Cycle: Experimentation and Performance among the Hollywood Studio Heads. Strategic Management Journal, 22, 725-745. http://dx.doi.org/10.1002/smj.171

[28] Vintilla, G. and Ghergina, S.C. (2012) An Empirical Investigation of the Relationship between Corporate Governance Mechanisms, CEO Characteristics and Listed Companies’ Performance. International Business Research, 5, 175-191.

[29] Becker, G. (1974) Human Capital: A Theoretical and Empirical Analysis, with Special Reference to Education. University of Chicago Press, Chicago.

[30] Chung, K.H. and Pruitt, S.W. (1996) Executive Ownership, Corporate Value and Executive Compensation: A Unifying Framework. Journal of Banking and Finance, 20, 1135-1159. http://dx.doi.org/10.1016/0378-4266(95)00039-9

[31] Main, B.G.M., O’Reilly, C.A. and Wade, J.B. (1995) The CEO, the Board of Directors and Executive Compensation: Economic and Psychological Perspectives. Industrial and Corporate Change, 4, 293-332. http://dx.doi.org/10.1093/icc/4.2.293

[32] Villalonga, B. and Amit, R. (2006) How Do Family Ownership, Management, and Control Affect Firm Value? Journal of Financial Economics, 80, 385-417. http://dx.doi.org/10.1016/j.jfineco.2004.12.005

[33] Palia, D., Ravid, S.A. and Wang, C.J. (2008) Founder versus Non-Founder in Large Companies: Financial Incentives and the Call for Regulation. Journal of Regulatory Economics, 33, 55-86. http://dx.doi.org/10.1007/s11149-007-9042-z

[34] Adams, R., Almeida, H. and Ferreira, D. (2009) Understanding the Relationship between Founder-CEOs and Firm Performance. Journal of Empirical Finance, 16, 136-150. http://dx.doi.org/10.1016/j.jempfin.2008.05.002

[35] Fahlenbrach, R. (2009) Founder CEOs, Investment Decisions, and Stock Market Performance. Journal of Financial and Quantitative Analysis, 44, 439-466. http://dx.doi.org/10.1017/S0022109009090139 